\title{
TRANSFERÊNCIA DE RESISTÊNCIA ANTIMICROBIANA ENTRE ENTEROBACTÉRIAS PATOGÊNICAS DE IMPORTÂNCIA AVIÁRIA - IMPACTOS EM SAÚDE PÚBLICA
}

\author{
(Transfer of antimicrobial resistance between avian pathogenic enterobacteria of \\ importance - Impacts on public health)
}

\author{
Tarcísio Macedo Silva ${ }^{1}$, Elisane Lenita Milbradt, João Carlos Zamae, Raphael Lúcio \\ Andreatti Filho, Adriano Sakai Okamoto
}

${ }^{1}$ Correspondência: tarcisiomedvet@hotmail.com

RESUMO: Ligações entre o uso indiscriminado de antimicrobianos na produção de animais, que se destinam à alimentação humana, conferindo pressão seletiva sobre microrganismos, e uma emergência na sua existência, surgimento, disseminação e transferência de genes que conferem de resistência a drogas antimicrobianas constituí preocupação global crescente. Processos de resistência antimicrobiana ocorrem de modo natural ou adquirido, sendo a maneira adquirida a mais preocupante. Vários são os mecanismos de transferência de resistência antimicrobiana, sobretudo elementos genéticos móveis são determinantes ao desenvolvimento de cepas bacterianas resistentes. Enterobactérias são frequentemente isoladas em produtos avícolas, sendo relatada múltipla resistência antimicrobiana e surtos de doenças em humanos. $O$ objetivo da presente revisão foi discutir e expor aspectos relacionados à transferência de resistência antimicrobiana, destacando os impactos da utilização de antimicrobianos e o processo de transferência de resistência antimicrobiana entre bactérias patogênicas, zoonóticas e comensais de aves.

Palavras-chave: transferência, genes, resistência, antimicrobianos, saúde-pública

ABSTRACT: Links between the indiscriminate use of antimicrobial agents in the production of animals which are intended for human consumption, conferring selective pressure on micro-organisms, and an emergency in its existence, appearance, dissemination and transfer of genes that confer resistance to drugs antimicrobial. Thus constitutes a global concern growing. Antimicrobial resistance processes occurs naturally or acquired, being the way acquired the most worrying. There are several mechanisms for transfer of antimicrobial resistance, especially mobile genetic elements are critical to the development of resistant bacterial strains. Enterobacteria are frequently isolated from poultry products, being reported multiple antimicrobial resistance and outbreaks of diseases in humans. The aim of this review is discuss and expose aspects related to the transfer of antimicrobial resistance, highlighting the impacts of the use of antimicrobials and the process of transfer of antimicrobial resistance among pathogenic, zoonotic and commensals bacteria of poultry.

Key Words: Transfer, genes, resistance, antimicrobials, public-health 


\section{INTRODUÇÃO}

Ligações entre uso errôneo e indiscriminado de antimicrobianos na produção de animais os quais se destinam a alimentação humana, conferindo pressão seletiva sobre muitos microrganismos, bem como uma emergência na existência, surgimento, disseminação e transferência de genes que conferem resistência a drogas antimicrobianas nesses animais de produção e nos seres humanos tem constituído uma preocupação global crescente nos últimos anos (Chantziaras et al., 2013; Levy e Marshall, 2004).

Tal preocupação global e crescente remonta desde a década de 50 , onde uso indiscriminado de antimicrobianos na alimentação animal proporcionou o desenvolvimento de populações bacterianas resistentes, as quais posteriormente dificultariam um possível tratamento terapêutico (Fuller, 1989). No entanto, a mais importante preocupação quanto ao uso destes na alimentação animal, em especial na avicultura reside no fato dos mesmos contribuírem efetivamente com 0 aumento na prevalência de resistência de microrganismos patogênicos aos próprios animais e ao ser humano, ficando claro que a saúde dos animais os quais se destinam a alimentação humana encontra-se diretamente relacionada a saúde do homem (Titze e Palermo-Neto, 2005; Górniak e Spinosa, 2007).

Animais, principalmente as aves podem abrigar no trato intestinal bactérias patogênicas (Salmonella spp, Campylobacter spp., Yersinia, Listeria, Enterococcus spp., Escherichia coli) consistindo em potenciais reservatórios de doenças zoonóticas com importância em medicina veterinária e para o homem, e importantes elementos de risco, passíveis de serem veiculadas por meio de alimentos (Aarestrup, 1999; Wei et al., 2013). Quando expostas com frequência ao uso de antimicrobianos, tais bactérias podem selecionar e transportar genes de resistência para microrganismos não patogênicos e bactérias comensais da microbiota intestinal, constituindo em um grave potencial de ameaça para a saúde pública (Barza, 2002; Van Den Bogaard et al., 2001).

Diante da relevância desse tema, essa revisão tem como propósito discutir e expor aspectos relacionados à transferência de resistência antimicrobiana entre microrganismos patogênicos com importância aviária, destacando os sérios riscos e impactos na saúde pública. Associando o uso de antimicrobianos em animais de produção como as aves com o processo de transferência e aquisição de genes resistência antimicrobiana entre importantes bactérias patogênicas, zoonóticas, comensais de notificação obrigatória (Brasil, 2009; OIE, 2014) das aves.

\section{A RESISTÊNCIA BACTERIANA A ANTIMICROBIANOS}

O uso de agentes antimicrobianos, tanto para animais quanto para humanos, implica em riscos potenciais para a seleção de bactérias resistentes, bem como na dinâmica de resistência antimicrobiana em uma população bacteriana (Schwarz et al., 2001).

O processo de resistência bacteriana consiste na capacidade de sobrevivência de um microrganismo frente de agentes antimicrobianos, em qualquer dose, concentração ou intervalo de tempo. Nessa situação a exposição bacteriana frente aos agentes induzem as bactérias a adaptarem-se a tal condição ou até mesmo a mortalidade dessas, esse processo recebe 0 nome de pressão seletiva. Define-se que exista uma estreita associação, entre a taxa de 
desenvolvimento de resistência e as quantidades de antimicrobianos utilizadas (Aarestrup, 1999; Titze e Palermo-Neto, 2005; Górniak e Spinosa, 2007).

De modo geral, o processo de resistência bacteriana pode ocorrer como processo natural intrínseco, ou por meio de resistência adquirida na qual ocorre a transferência horizontal ou lateral de genes de resistência tanto cromossômica como extracromossômica, por meio de: transdução, conjugação, transformação ou transposição de genes. A propensão bacteriana em adaptar-se a novos ambientes e nichos ecológicos, o aumento da infectividade e a capacidade de colonização constituem também fatores importantes dentro do processo de resistência (Barata, 1997; Spinosa et al., 2005).

Apesar desses fatores envolvidos a resistência de microrganismos só ocorrerá quando houver pressão seletiva, na ausência desse processo os níveis de resistência são muito baixos, havendo poucas chances para falhas terapêuticas (Helmuth, 2000). Bactérias resistentes ao processo de pressão seletiva podem espalhar-se, transportando e propagando genes de resistência, essa propagação de resistência se dá por contato direto com animais, ou indiretamente por meio de alimentos de origem animal, água e resíduos agropecuários (Marshall e Levy, 2011; Górniak e Spinosa, 2007).

É inegável que o panorama atual não seja muito diferente da época em que marca a descoberta e o uso das drogas antibióticas. Diversos estudos, antigos e recentes (Álvarez -Fernández et al., 2012; Dallal et al., 2010; Sonalli et al., 2012; Van Den Bogaard et al., 2001) abordando o tema resistência antimicrobiana retratam resultados desfavoráveis quanto à sensibilidade bacteriana a várias drogas comuns ao uso veterinário e humano, sendo demonstrado aumento preocupante e emergente nas taxas de resistência de importantes bactérias patogênicas, zoonóticas e comensais veiculadas em produtos e subprodutos avícolas em diversos países.

Instituições

regulamentares demonstram-se preocupadas em evitar ou reduzir os impactos negativos potenciais resultantes da utilização de agentes antimicrobianos e resistência antimicrobiana em animais produtores de alimentos sobre a saúde pública. Medidas vem sendo adotadas no intuito de proteger a saúde do consumidor, garantindo de modo segurança dos alimentos de origem animal destinados ao consumo humano ou reduzir tanto quanto possível a transferência direta e indireta de resistência entre microrganismos patogênicos ou determinantes de resistência antimicrobiana nas populações de animais e humanos (Codex, 2005).

$\mathrm{Na}$ avicultura, a utilização de antimicrobianos como aditivos com função de promoção de melhoria no desempenho zootécnico, tem acarretado em pressão seletiva e alterações sobre diferentes espécies bacterianas presentes na flora intestinal, favorecendo o surgimento e proliferação de cepas resistentes e a transferência dessas entre indivíduos da criação (Titze e Palermo-Neto, 2005). Em 2008 a União Europeia UE baniu o uso todos antibióticos como promotores de crescimento na alimentação animal, visando manter as exportações brasileiras de carne de frango para a UE no Brasil algumas drogas já foram proibidas (Brumano e Gattás, 2009) e várias pesquisas com enzimas, prebióticos, probióticos e vacinas com ação sobre muitos microrganismos patogênicos e zoonóticos substituindo os efeitos benéficos dos antimicrobianos na avicultura vem sendo desenvolvidas. 


\section{A TRANSFERÊNCIA RESISTÊNCIA ANTIMICROBIANA}

Entre as bactérias muitos genes são adquiridos de forma horizontal ou lateral, ao se expressarem alguns desses genes são passíveis de causar efeitos deletérios no genoma do microrganismo receptor ou em uma população bacteriana inteira, essas informações também são capazes de ter um efeito insignificante, ou serem retidas, proporcionando vantagens seletivas ou codificarem elementos com funções importantes no processo de transferência de resistência e na sua manutenção (Gogarten e Townsend, 2005; Thomas e Nielsen, 2005).

Atualmente é amplamente reconhecido que este mecanismo Horizontal Gene Transfer (HTG) seja responsável por desempenhar um importante papel na aquisição, evolução a distribuição de genes que conferem resistência a antibióticos, além de conferir características de virulência e metabólicas a algumas espécies bacterianas (De La Cruz e Davies, 2000).

Como mencionado os microrganismos adquirem resistência por mutações ou pela aquisição de genes a partir de outras bactérias. A resistência adquirida configura-se como a mais preocupante, decorrente aos grandes impactos para a terapêutica (Spinosa et al., 2005).

$A$ aquisição de material genético entre bactérias, mediante 0 processo de transferência horizontal de genes que conferem resistência a antimicrobianos acontece mediante vários processos, os quais consistem em: "Transformação" processo no qual as bactérias capturaram fragmentos de DNA livre e incorporam ao seu genoma, podendo incorporar genes de resistência de cepas resistentes. "Transdução" transferência de genes de resistência entre microrganismos mediado por meio de bacteriófagos, "Conjugação"
Transferência por contato direto e entre uma bactéria doadora e receptora, esse processo de intercâmbio confere a transferência DNA plasmidial resistente, transposons e integrons de uma bactéria doadora para a bactéria receptora por meio de pili conjugativo. "Transposição" Transferência de transposons (sequências de DNA), que pode ocorrer do cromossomo bacteriano para um plasmídeo ou vice e versa, ou para um bacteriófago (Murray et al., 2009; Spinosa et al., 2005; Tenover, 2006; Zaneveld et al., 2008).

Embora seja relevante o papel de todos esses mecanismos e elementos genéticos no processo de HGT, qualquer um desses processos podem promover resistência antimicrobiana. Predominantemente, processos de mutação, transdução e transformação constituem formas de resistência entre Gram-positivas, já entre bactérias Gram negativas essas três formas são passíveis de ocorrerem, havendo predominância do processo de transposição (Spinosa et al., 2005).

Sobretudo admite-se que os elementos genéticos móveis como plasmídeos, transposons e integrons são determinantes ao desenvolvimento de cepas bacterianas resistentes a antimicrobianos, decorrente a diversidade na transmissão de genes (De La Cruz e Davies, 2000; Dionisio et al., 2002; Norman et al., 2009; Ochman et al., 2000).

Plasmídeos possuem um papel de grande importância na HTG, sua capacidade de replicação autônoma (extracromossômica), aliada a sua mobilidade e a capacidade de transferência genes por conjugação os conferem vantagens seletivas, o que proporciona 0 transporte diferentes traços em diferentes ambientes conferindo adaptabilidade. Outro fator que contribui para a dada importância os plasmídeos reside na não especificidade para transferir DNA, 
podendo 0 organismo receptor pertencer a diferentes gêneros e reinos "bactérias, fungos, plantas, animais e humanos" (Sørensen et al., 2005).

Durante o processo de conjugação, o DNA plasmidial é cortado em um ponto de origem de transferência chamado (oriT) levando a replicação e a transferência deste, entre a célula doadora e receptora. Plasmídeos transportam fatores $R$ os quais conferem transferência e são determinantes para a resistência antimicrobiana a diversas drogas (Hemulth, 2000). Estudos envolvendo fatores $\mathrm{R}$ e outros genes existentes em plasmídeos demonstram ser comum a existência destes em cepas bacterianas resistentes a antimicrobianos (Bennett e Richmond, 1976).

Elementos genéticos transponíveis (Transposons) codificam funções para ocorrência de transposição intracelular e conjugação intercelular de DNA, presentes em um número expressivo de bactérias estes conferem características fenotípicas selecionáveis (Norman et al., 2009; Ochman et al., 2000). Transposons encontram-se inseridos em plasmídeos e permitem a inserção de genes cassetes, integrons e enzimas capazes de facilitar a deleção de genes ou promover a captura e o acréscimo de elementos genéticos responsáveis por resistência antimicrobiana (Norman et al., 2009).

Integrons constituem elementos de aquisição de genes, genes capturados por integrons sofrem recombinação em um sistema específico capaz de transformá-los em genes funcionais, desse modo é garantido um funcionamento e a correta expressão gênica (Mazel, 2006). Integrons não são móveis, e não expressam genes de auto mobilidade, no entanto codificam e permite a expressão de unidades menores de DNA "genes cassetes", tais genes estão implicados na resistência e no processo de transferência de resistência a drogas antimicrobianas (Zaneveld et al., 2008; Mazel, 2006).

\section{A TRANSFERÊNCIA DE RESISTÊNCIA ENTEROBACTÉRIAS COM IMPORTÂNCIA AVIÁRIA E EM SAÚDE PÚBLICA}

Bactérias resistentes a antibióticos que causam infecções zoonóticas em seres humanos podem ser atribuídas a fontes animais. No entanto, uma vez que estas atingem a população humana esses agentes podem disseminar sobre diferentes modos entre os seres humanos (Schwarz et al 2001). A microbiota intestinal das aves é composta por uma grande diversidade de microrganismos, principalmente por enterobactérias, estas podem ser classificadas como comensais ou patogênicas e zoonóticas (Wei et al., 2013).

Enterobactérias patogênicas Salmonella spp, Campylobacter spp., Yersinia, Listeria, Enterococcus spp. e Escherichia coli são frequentemente isoladas em materiais e produtos avícolas, estas possuem importância médico veterinária e de saúde pública, pois são também agentes patogênicos para as aves, outros animais e ao homem, sendo veiculados em alimentos contaminados (Titze e Palermo-Neto, 2005; Dallal et al., 2010) e relatadas frequentemente em episódios de múltipla resistência a diversos antimicrobianos (Álvarez-Fernández et al., 2012; Dallal et al., 2010; Sonali et al., 2012; Van Den Bogaard et al., 2001).

Como relatado, plasmídios encontramse envolvidos no processo de transferência gênica de resistência entre bactérias. Barros et al. (2012) realizaram estudos envolvendo pesquisas de plasmídeos presentes em amostras de $E$. coli isoladas de frangos 
de corte e poedeiras comerciais, tais autores detectaram plasmídeos com alto peso molecular na maioria dos isolados, sendo possível indicar associação com a resistência a antimicrobianos, sugerindo a ocorrência de transferência de genes entre diferentes bactérias, patogênicas e não patogênicas, as quais poderiam ser responsáveis pela manutenção de um "pool" gênico ligado a processos de patogênese na população bacteriana.

Van Den Bogaard et al. (2001) objetivando analisar a possibilidade de transferência de resistência à ciprofloxacina entre $E$. coli provenientes de aves e seres humanos obtiveram resultados que indicaram fortemente que a transmissão de clones resistentes e plasmídeos resistentes entre aves e humanos ocorre.

Integrons classificam-se em cinco classes, tais classes se associam fisicamente a elementos gênicos móveis do DNA "sequências de inserção (ISS), transposons, e plasmídeos conjugativos". No que diz a respeito do processo de resistência entre membros da família Enterobacteriaceae, integrons classes 1 e 2 são os principais envolvidos. Classe 1: relacionam se com o funcionamento e o não funcionamento de transposons Tn402 e Tn21; Classe 2: relacionam-se a transposons derivativos Tn7 (Desie et al., 2013; Mazel, 2006).

Desie et al. (2013) ao caracterizarem a resistência antimicrobiana associando com a presença de integrons e genes cassetes em 99 amostras de E.coli e 33 de Salmonella isoladas a partir de fezes e carcaças de frango de aves domésticas na Korea, encontraram resistência a múltiplas drogas em $85,8 \%$ e $63,6 \%$ dos isolados de E.coli e de Salmonella respectivamente. Um total de $70(70,7 \%)$ e $3(9,1 \%)$ integrons foram detectados em $E$. coli e Salmonella respectivamente, maior parte dos integrons encontrados em $E$. coli eram multidroga resistentes, $87 \%$ dos integrons detectados em E. coli abrigaram cassetes de genes que conferem resistência a diversos antimicrobianos. Os principais genes cassetes encontrados foram aadA1+dfrA1 e dfrA1+sat2+aadA1 em integrons classe 1 e na classe 2.

Os resultados anteriormente citados sugerem similaridade em genes responsáveis pelos perfis de resistência, - que denota fonte potencial de disseminação de resistência para outras bactérias, além de apontar altos índices de resistência, indicando a necessidade de interesses especiais, principalmente no tocante de saúde pública, pois a maioria dos isolados resistentes podem transportar integrons com cassetes resistentes os quais poderiam ser responsáveis pelos perfis de resistência antimicrobiana para o ser humano.

Análises a respeito da transferência horizontal de genes por meio de conjugação com transferência de integron classe 1 em amostras de $E$. coli intestinais e extraintestinais de aves realizadas por Nórgrády et al. (2006) sugerem que muitas dessas bactérias podem conter diferentes combinações de elementos de resistência dentro dos integrons classe 1 frente a: cloranfenicol, estreptomicina, tetraciclina, gentamicina, canamicina, sulfametoxazol-trimetoprim, cefotaxima, ácido nalidíxico e ciprofloxacina além de possuírem diferentes genes de virulência "COIV, Iss e Tsh". Esses resultados possuem de grande relevância, haja vista que, os mesmos sugerem que as cepas estudadas podem atuar como um potencial reservatório para propagação de genes de resistência e virulência frente as drogas estudadas.

Existem poucos estudos epidemiológicos sobre prevalência de Listeria spp. atuando como reservatórios de genes de resistência a antibióticos (Bertsch et al., 2014). Listeria 
monocytogenes persistem como sendo em importantes patógenos veiculados em produtos alimentares de origem aviária (Dhama et., 2013). Evidências observadas por Alonso-Hernando et al. (2012) onde estirpes bacterianas de $L$. monocytogenes resistentes isoladas de carcaças de aves representaram alta prevalência nos perfis de resistência antimicrobiana, o que vem apresentar riscos para a saúde humana, sugerindo que esses isolados bacterianos semelhantes aos estudados podem ser transmitidos para humanos através do contato ou por meio do consumo. O controle dessas amostras resistentes, e os genes relacionados aos processos de resistência antimicrobiana demandam medidas preventivas tanto no surgimento quanto na propagação dos mesmos, cuidados no processamento de alimentos, preparação e o consumo de alimentos constituem meios de prevenção e controle de aparecimento dessas.

Pérez-Diaz et al. (1982) relatam que a resistência aos antibióticos em $L$. monocytogenes é causada por elementos genéticos móveis, como plasmídeos autotransferíveis, plasmídeos móveis e transposons conjugativos. O plasmídeo pIP501, tem uma ampla gama de hospedeiros e confere resistência as drogas: cloranfenicol, macrólideos, lincosamidas e estreptograminas, tal plasmídeo replica-se dentro da dessa espécie bacteriana, bem como o mesmo pode ser transferido entre outras espécies. Estudos recentes realizados por Bertsch et al. (2013) reforçam resultados antigos acerca da replicação de plasmídeos no gênero bacteriano em questão, onde o plasmídeo "pDB2011" isolado em Listeria innocua alberga genes multirresistentes. Os achados desse estudo confirmam que o plasmídeo estudado pode se replicar entre espécies bacterianas Gram-positivas e Gram-negativas.
Por outro lado Bertsch et al. (2014) ao tentar elucidar 0 potencial de transmissibilidade horizontal dos genes de resistência isolados de Listeria spp. oriundas de produtos cárneos, lácteos, peixes/frutos do mar, materiais vegetais, água, aves e seres humanos descreve que seja relativamente baixo o número de cepas bacterianas dessa espécie que constituem reservatórios de resistência a antibióticos. Amostras que apresentaram baixos níveis de resistência foram estudadas com a finalidade de verificar a transferência de genes de resistência. Contudo foi observado que seja relativamente a comum a presença de genes de resistência à tetraciclina em transposons móveis em bactéria doadora e receptora, havendo preocupações com a possibilidade de que a transferência desses genes resistências espalhem futuramente, tal fato reforça ideia da importância de vigilância epidemiológica no sentido do monitoramento da sensibilidade antimicrobiana.

Campilobacterioses constituem um grande problema de saúde pública sendo uma das causas responsáveis por quadros de gastroenterites de origem alimentar em humanos, dada as preocupações de saúde pública para com agentes zoonóticos evidências obtidas por Wimalarathana et al. (2013) corroboram para com a compreensão de aquisição de resistência entre Campylobacter jejuni e Campylobacter coli isolados de aves. Resultados investigativos e temporais obtidos em longo prazo revelam a presença generalizada de resistência antimicrobiana em clusters dentro das linhagens os quais podem ser difundidos de modo não aleatório, sugerindo que 0 processo de transferência horizontal de genes tenha um papel importante na aquisição e transmissão de clusters de linhagens resistentes entre os microrganismos estudados. Considerando as aves como 
importantes reservatórios de

Campylobacter para humanos a resistência generalizada entre as amostras isoladas em aves sejam susceptíveis de promover consequências de longo alcance na saúde pública.

Okamoto et al. (2011) relatam a possibilidade e propensão de bactérias não patogênicas, e benéficas intestinais das aves "Lactobacillus spp." atuarem como reservatórios de genes de resistência de importantes cepas bacterianas "Salmonella Enteritidis, $E$ coll" patogênicas para as aves e o ser humano. Esse processo aquisição de genes resistência entre bactérias não patogênicas e benéficas intestinais foi bem relatado e revisado por Teuber et al. (2009) em outras espécies de animais, tais autores descrevem a transferência de plasmídeos e transposons conjugativos como responsáveis pela transferência de resistência antimicrobiana entre bactérias ácido láticas presentes em alimentos.

\section{O IMPACTOS EM SAÚDE PÚBLICA}

É importante dizer que a resistência aos antibióticos constitui uma significativa ameaça à saúde pública (Holloway et al., 2000; Williams et al., 2000) os novos comportamentos epidemiológicos de doenças antigas, bem como o surgimento de agentes bacterianos resistentes a várias drogas antimicrobianas, que até certo ponto não eram previstos atualmente já são observados, estando diretamente relacionadas à saúde pública. $A$ magnitude dessas informações indicam alterações importantes nos processos resistência, infectividade e patogenicidade de vários agentes, podendo estar relacionadas a habilidade e versatilidade genética de genes carregados por elementos extracromossômicos presentes nos microrganismos (Barata, 1997).

Seres humanos encontram-se expostos a importantes bactérias zoonóticas resistentes, através de contato direto com animais ou por meio do consumo de produtos de origem animal. Através dessa exposição e contato, tais bactérias resistentes podem colonizar o ser humano e transferirem ou não resistência de genes para outras bactérias pertencentes à flora microbiana do homem, além disso, quanto maior 0 número de microrganismos intestinais resistentes, maiores serão os riscos dos genes codificarem resistência e serem transferidos para outras bactérias e consequentemente serem eliminadas no meio ambiente ou veiculados nos alimentos de origem animal (Van Den Bogaard e Stobberingh, 2000).

Dados atuais internacionais revelam correlações elevadas entre o uso de antimicrobianos e resistência antimicrobiana em animais produtores de alimentos para humanos, principalmente aves, demostrando preocupação global (Chantziaras et al., 2013). As evidências apontadas são inegáveis que as aves, bem como alimentos de origem aviária podem atuar como reservatórios de bactérias resistentes e de genes que caracterizam resistência antimicrobiana, o que vem representar riscos à saúde dos seres humanos (Marshall e Levy, 2011).

\section{CONCLUSÃO}

Com base nas presentes evidências processos de transferência de resistência antimicrobiana entre enterobactérias patogênicas com importância aviária demonstram preocupação global. A habilidade e versatilidade genética dos genes carregados por elementos extracromossômicos presentes nos 
microrganismos respondem ao panorama apresentado de transferência de resistência antimicrobiana, bem como pelo aumento nos processos de patogênese e virulência nas enfermidades provocadas por enterobactérias. A possibilidade e propensão de bactérias não patogênicas e benéficas intestinais das aves atuarem como potenciais reservatórios de genes de resistência antimicrobiana traduz-se em riscos para a saúde animal e humana, sendo passível afirmar que haja a ocorrência de graves consequências para saúde das aves e no controle de importantes doenças, comuns entre as aves e o homem.

\section{REFERÊNCIAS}

ALONSO-HERNANDO. A.; PRIETO, M.; GARCÍA-FERNÁNDEZ C. et al. Increase over time in the prevalence of multiple antibiotic resistance among isolates of Listeria monocytogenes from poultry in Spain. Food Control, v.23, n.1, p.37-41, 2012.

ÁLVAREZ-FERNÁNDEZ, E.; ALONSOCALLEJA, C.; GARCÍA-FERNÁNDEZ, C. et al. Prevalence and antimicrobial resistance of Salmonella serotypes isolated from poultry in Spain: comparison between 1993 and 2006 . International Journal of Food Microbiology, v.153, p.281-287, 2012.

AARESTRUP, F. M. Association between the consumption of antimicrobial agents in animal husbandry and the occurrence of resistant bacteria among food animals. International Journal of Antimicrobial Agents, v.12, p.279-285,1999.

BARATA, R.C.B. O desafio das doenças emergentes e a revalorização da epidemiologia descritiva. Revista Saúde Pública, v.31, n.5, p.531-537, 1997.
BARROS, M.R.; SILVEIRA, W.D.; ARAÚJO, J.M.D. et al. Antimicrobial resistance and plasmidial profile of Escherichia coli strain isolated from broilers and commercial layers in the state of Pernambuco, Brazil. Pesquisa Veterinária Brasileira, v.32, n.5, p.405410, 2012.

BARZA, M. Potential mechanisms of increased disease in humans from antimicrobial resistance in food animals. Clinical Infectious Diseases, v.34: Suppl.3, S123-S125, 2002.

BENNETT, P.M.; RICHMOND, M. H. Translocation of a Discrete Piece of Deoxyribonucleic Acid Carrying an amp Gene Between Replicons in Escherichia coli. Journal of Bacteriology, v.126, n.1, p.1-6, 1976.

BERTSCH, D.; ANDEREGG, J.; LACROIX, C. et al. pDB2011, a $7.6 \mathrm{~kb}$ multidrug resistance plasmid from Listeria innocua replicating in Grampositive and Gram-negative hosts. Plasmid, v.70, n.2, p.284-287, 2013.

BERTSCH, D.; MUELLI, M.; WELLER M. et al. Antimicrobial susceptibility and antibiotic resistance gene transfer analysis of foodborne, clinical, and environmental Listeria spp. isolates including Listeria monocytogenes. Microbiology Open, v.3, n.1, p.118127, 2014.

BRASIL - Ministério da Agricultura, Pecuária e Abastecimento. Secretaria de Defesa Agropecuária. Departamento de Saúde Animal. Manual Técnico. Manual de Legislação. Programas Nacionais de Saúde Animal do Brasil, Brasília, 2009, 440p.

$\begin{array}{lrrr}\text { BRUMANO, G.; } & \text { GATTÁS, } & \text { G. } \\ \text { Implicações sobre } & \text { o uso } & \text { de } \\ \text { antimicrobianos em rações } & \text { de }\end{array}$ monogástricos. Revista Eletrônica Nutritime, v.6, n.3, p.953-959, 2009.

CHANTZIARAS, I.; BOYEN, F.; CALLENS, B. et al. Correlation between 
veterinary antimicrobial use and antimicrobial resistance in foodproducing animals: a report on seven countries. Journal of Antimicrobial Chemotherapy, v.68, n.11, p.1-8, 2013.

CODEX ALIMENTARIUS. [2005]. Code of practice to minimize and contain antimicrobial resistance. CAC/RCP 61$2005 . \quad$ Disponível em: http://www.codexalimentarius.net/input/.. /CXP 061e.pdf Acesso em: 02/03/2015.

DHAMA, K.; VERMA, A.K.; RAJAGUNALAN, S. et al. Listeria monocytogenes infections in poultry and its public health importance with special reference to food borne zoonoses. Pakistan Journal of Biological Sciences. v.16, n.7, p.301-308, 2013.

DALLAL, M.M.S.; DOYLE, M.P.; REZADEHBASHI, M. et al. Prevalence and antimicrobial resistance profiles of Salmonella serotypes, Campylobacter and Yersinia spp. isolated from retail chicken and beef, Tehran, Iran. Food Control, v.21, n.4, p.388-392, 2010.

DE LA CRUZ, I.; DAVIES, J. Horizontal gene transfer and the origin of species: lessons from bacteria. Trends Microbiology, v.8, n.8, p.128-133, 2000.

DESSIE, H.K.; BAE, D.H.; LEE, Y.J Characterization of integrons and their cassettes in Escherichia coli and Salmonella isolates from poultry in Korea. Poultry Science, v.92, n.11, p.3036-3046, 2013.

DIONISIO, F.; MATIC, I.; RADMAN, M. et al. Plasmids spread very fast in heterogeneous bacterial communities. Genetics, v.162, n.4, p.525-1532, 2002.

FULLER, R. Probiotics in man and animals. A review. Journal of Applied Bacteriology, v.66, n.5, p.365-378, 1989.
GOGARTEN, J.R; TOWNSEND, J.P. Horizontal gene transfer, genome innovation and evolution. Nature Reviews Microbiology, v.3, n.9, p.679687, 2005.

GÓRNIAK, S.L.; SPINOSA, H.S. Antimicrobianos na Avicultura-Usos e Restrições. In: ANDREATTI FILHO, R.L. Saúde Aviária e Doenças. São Paulo: Roca, 2007, p.35-40.

HEMULTH, R. Antibiotic Resistance in Salmonella. In: WRAY, C.; WRAY, A. Salmonella in Domestic Animals. (Eds). New York-USA: CABI Publishing, 2000, Cap.6, p.89-106.

HOLLOWAY, K. Antimicrobial resistance: the facts. Essential Drug Monitor WHO. v.28, n.29, p.7-8, 2000.

LEVY, S.B.; MARSHALL, B. Antibacterial resistance worldwide: causes, challenges and responses. Nature Medicine Supplement, v.10, n.12, S122-S129, 2004.

MARSHALL, B.M.; LEVY, S.B. Food animals and antimicrobials: impacts on human health. Clinical Microbiology Reviews, v.24, n.4, p.718-733, 2011.

MAZEL, D. Integrons: agents of bacterial evolution. Nature Reviews Microbiology, v.4, n.8, p.608-620, 2006.

MURRAY, P.R.; ROSENTHAL, K.S.; PFALLER, M.A. Microbiologia Médica. 6.ed, Rio de Janeiro: Elsevier, 2009. 948p.

NÓGRÁDY, N.; PÁSZTI, J.; PIKÓ, H. et al. Class1 integrons and their conjugal transfer with and without virulenceassociated genes in extra intestinal Escherichia coli of poultry. Avian Pathology, v.35, n.4, p.349-356, 2006.

NORMAN, A.; HANSEN, L.H.; SORENSEN, S.J. Conjugative plasmids: vessels of the communal gene pool. Philosophical Transactions Royal. 
Society, v.364, n.1527, p.2275-2289, 2009.

OCHMAN, H.; LAWRENCE, J.G.; GROISMAN, E.A. Lateral gene transfer and the nature of bacterial innovation. Nature, v.405, n.6784, p.299-304, 2000.

OKAMOTO, A. S.; ANDREATTI FILHO, R.L.; ROCHA, T.S. et al. Transference in vitro of the resistance to the antimicrobials between Escherichia coli, Lactobacillus spp. and Salmonella enteritidis isolated from chickens. Arquivo Brasileiro de Medicina Veterinária e Zootecnia, v.63, n.5, p.1149-1153, 2011.

OIE. [2014]. Doenças OIE cotadas, infecções e infestações em vigor em 2014. Disponível em: http://www.oie.int/animal-health-in-theworld/oie-listed-diseases-2014/ Acesso em: 02/03/ 2015.

PÉREZ-DÍAZ, J.C.; VICENTE, M.F.; BAQUERO, $F$. Plasmids in Listeria. Plasmid, v.8, n.2, p.112-118, 1982.

SCHWARZ, S.; KEHRENBERG, C.; WALSH T.R. Use of antimicrobial agents in veterinary medicine and food animal production. International Journal of Antimicrobial Agents. v.17, n.6, p.431437, 2001.

SONALI, M. R.C.; GRANDA, A.E.; FELIPE, L. et al. Resistencia antimicrobiana en cepas de Salmonella enterica subsp. enterica aisladas en carnes de aves importadas. Revista de Salud Animal, v.34, n.2, p.120-126, 2012.

SØRENSEN, S.J.; BAILEY, M.; HANSEN, L.H. et al. Studying plasmid horizontal transfer in situ: critical review. Nature Reviews Microbiology, v.3, n.9, p.700-710, 2005.

SPINOSA, H.S.; ITO, N.M.K.; MIYAJI, C.I.; et al. Antimicrobianos: considerações gerais. In: PALERMONETO J.; SPINOSA, H.S.; GORNIAK
S.L. Farmacologia Aplicada a Avicultura. 1.ed. São Paulo: Roca, 2005, p.87-103.

TENOVER, F. C. Mechanisms of Antimicrobial Resistance in Bacteria. The American Journal of Medicine, v.119, n.6A, p.53-510, 2006.

TEUBER, M.; MEILE, L.; SCHWARTZ, $F$. Acquired antibiotic resistance in lactic acid bacteria from food. Antonie van Leeuwenhoek, v.76, n.1-4, p.115-137, 1999.

THOMAS, C.M.; NIELSEN, K.M. Mechanisms of, and barriers to, horizontal gene transfer between bacteria. Nature Reviews Microbiology, v.3, n.9, p.711-721, 2005.

TITZE, R.A.; PALERMO-NETO, J. Uso de antimicrobianos em avicultura e 0 desenvolvimento de resistência bacteriana. In: PALERMO-NETO, J.; SPINOSA, H.S; GÓRNIAK, S. L. Farmacologia aplicada à avicultura. 1.ed. São Paulo: Roca, 2005, p.161173.

VAN DEN BOGAARD, A.E.; LONDON, N.; DRIESSEN, C. et al. Antibiotic resistance of faecal Escherichia coli in poultry, poultry farmers and poultry slaughterers. Journal of Antimicrobial Chemotherapy, v.47, n.6, p.763-771, 2001.

VAN DEN BOGAARD, A.E.; STOBBERINGH, E.E. Epidemiology of resistance to antibiotics Links between animals and humans. International Journal of Antimicrobial agents, v.14, n.4, p.327-335, 2000.

ZANEVELD, J. R.; NEMERGUT, D. R.; $\mathrm{KNIGHT}$, R. Are all horizontal gene transfers created equal? Prospects for mechanism-based studies of HGT patterns. Microbiology, v.154, n.1, p.115, 2008.

WEI, S.; MORRISON, M.; YU, Z. Bacterial census of poultry intestinal 
microbiome. Poultry Science, v.92, n.3, p.671-683, 2013.

WILLIAMS, R. Antimicrobial resistance: a global threat. Essential Drug Monitor WHO. v.28, n.29, p.1, 2000.

WIMALARATHNA, H.M.;

RICHARDSON, J.F.; LAWSON, A. et al. Widespread acquisition of antimicrobial resistance among Campylobacter isolates from UK retail poultry and evidence for clonal expansion of resistant lineages. BMC microbiology, v.13, n.1, p.160, 2013. 